УДК 336.77.067.22

JEL: G32

DOI: http://doi.org/10.32750/2019-0105

\author{
Підвисочький Ян Володимирович \\ Кандидат економічних наук, асистент \\ Київський національний університет імені Тараса Шевченка, \\ Інститут міжнародних відносин, \\ м. Київ, Україна \\ ORCID ID 0000-0001-7944-6248 \\ e-mail:yanpidvysotskiy@gmail.com
}

\title{
ПРОБЛЕМИ ОЦІНКИ КРЕДИТНИХ РИЗИКІВ СТРУКТУРОВАНИХ ФІНАНСОВИХ ІНСТРУМЕНТІВ
}

\begin{abstract}
Анотація. Підходи до оцінки ризиків структурованих фінансових інструментів, а саме цінних паперів, забезпечених активами, у сучасній фінансовій інженерії є недостатньо систематизованими. Причинами чього можуть стати розмаїття ризиків, які банк бажає уникнути, передавши в управління іншим сторонам; неналежна увага до селекції позичальників; відсутність консолідації з питань формування єдиної методики оцінки типових ризиків.

Автор подає для аналізу три головні види ризиків, з якими стикається банк у прочесі здійснення сек'юритизаиії: ризик дострокового повернення кредиту, ризик зміни процентної ставки та ризик дефолту контрагента. Уоснові оцінок лежать фактори часу та події, які за певних умов можуть критично впливати на грошові потоки фінансових установ.

Ризики дострокового повернення пов'язані з розрахунком усереднених значень часу до настання виплат за кредитами, однак уніфікована методика оцінки у банківській практиці наразі відсутня. Оцінка ступеню ризику супроводжується обрахунком процентного приросту до базової ціни з незмінною доходністю. Приріст відображає ризик зміни прочентної ставки протягом певного 4асу.

Особливу увагу у статті автор приділив аналізу методів оцінки дефолту контрагента структурованого інструменту. Встановлено, що методика Е. Альтмана за різних умов економічного середовища може давати суперечливі результати. Тому в останні роки оптимальними моделями оцінки ризику дефолту можна вважати моделі нечітко-нейронних мереж. Взята за основу методика О.А. Недосєкіна показує ступінь ризику банкрутства позичальника, спираючись на методи експертних оцінок. 3 одного боку, модель нечітко-нейронних мереж може давати наближені до істини результати, з іншого - на точність результату може впливати асиметрія інформачії, на основі якої будує оцінку певний експерт. В такому ключі чя модель потребує подальших вдосконалень, які пропонують сучасні японські вчені на основі критерію Мамдані.

Таким чином, проблематика оцінки кредитних ризиків структурованих інструментів залишається актуальною у сучасних наукових колах та потребує вироблення спільних ідей уніфікації методик, які пропонуються сучасною наукою.
\end{abstract}

Ключові слова: кредитний ризик; структурований фінансовий інструмент; дострокове повернення; процентна ставка; дефолт.

\section{๑ Я. В. Підвисоцький, 2019}

\section{ВСТУП}

В управлінні системою ризиків кредитного характеру особливе місце займає грамотна, достовірна оцінка ступеню небезпек, які чи- нять вплив на функціонування фінансового інструменту, створюючи загрози учасникам фінансово-кредитних угод. Остання фінансово-економічна криза довела, що нехтування 
чи зменшення уваги до питання селективності позичальників за рядом параметрів, які впливають на характер кредитних відносин між сторонами, може призводити до масштабних потрясінь у фінансово-економічних системах країн світу. Структуровані фінансові продукти на ринку банківських послуг, в основі яких лежить механізм сек'юритизації та дезагрегації ризиків, мають бути оцінені для інвестора 3 точки зору надійності позичальників, адже останні виступають джерелом формування прибутків.

Постановка проблеми. У сучасній банківській практиці до цього часу відсутня єдина модель управління системою ризиків, пов'язаних $з$ їх передачею інвесторам на основі механізму сек'юритизаціі. Такий стан пояснюється необхідністю врахування і упорядкування множини параметрів, сутність яких можна звести до трьох категорій: параметр часу, випадкової події та поведінки суб'єкта кредитних відносин. Підходи до вирішення проблеми оцінки кредитних ризиків структурованих фінансових інструментів не систематизовані та не вивчені до кінця та потребують подальших досліджень.

Аналіз останніх досліджень і публікацій. Проблеми, пов'язані з оцінкою кредитних ризиків в цілому та ризиків структурованих фінансових інструментів зокрема розглядають такі вчені як: Слім Б. [1] Юелианг Су, Баою Жонг [4]. У статтях цих авторів розглядаються підходи до побудови математичних моделей з оцінки банківських ризиків кредитного характеру. У той же час Девідсон [3] спробував систематизувати ризики структурованих фінансових інструментів, показавши способи структурування активів за різними параметрами, такими, як час, випадкова подія чи поведінка контрагента фінансових угод. Велику увагу заслуговують праці А.О. Недосєкіна з оцінки дефолту позичальників, де він представив свою розробку методу нечітко-нейронних мереж з метою визначення рівня платоспроможності підприємств. [8; 9; 10]

Мета статті. Метою статті $€$ теоретичне узагальнення підходів до оцінки кредитних ризиків структурованих фінансових інструментів.

\section{РЕЗУЛЬТАТИ ДОСЛІДЖЕННЯ}

У системі структурованих фінансових інструментів передача ризиків банку, пов'язаних із кредитуванням, інвесторам передбачає наявність обставин, за якими дохід може бути не виплаченим, виплаченим частково чи із затримкою. Інвестор, купуючи структуровані цінні папери, виступає носієм кредитних ризи- ків, однак не може впливати на структуру пулу активів шляхом зміни параметрів. Тому для прийняття рішення про інвестування, наприклад, у цінні папери, забезпечені активами чи іпотекою, виникає необхідність оцінки складу позичальників з їх рейтингами та кредитними історіями.

При оцінці показників ризикованості цінних паперів ABS виділяють статичний та динамічний аналіз. Останній базується на статичних розрахунках показників ризикованості і враховує фактори зміни показників (наприклад, відсоткової ставки) в часі. [1]

У практиці структурування активів існує багато видів та підвидів ризиків, однак усіх їх можна розділити на три великих категоріі: ризики дострокового повернення, ризики процентних ставок та ризики дефолту контрагента.

Першим суттєвим ризиком, 3 яким стикається інвестор в ABS, є ризик дострокового повернення (погашення) боргу. Він обумовлений тим, що позичальник раніше встановленого у договорі строку повертає банку повну суму кредиту, і таким чином припиняє подальші виплати відсотків. Як правило, право дострокового погашення не передбачає для позичальника будь-яких санкцій. Повне чи часткове погашення супроводжується необхідністю пошуку додаткових ресурсів, а тому суттєво змінює грошовий потік в пулі активів, i, відповідно, дохідність інвестора.

В банківській практиці прийняті наступні методики оцінки розмірів дострокових повернень:

- $\mathrm{SMM} \mathrm{-} \mathrm{частка} \mathrm{дострокового} \mathrm{місячного} \mathrm{по-}$ вернення;

- $\mathrm{CPR}$ - умовний коефіцієнт дострокових повернень;

- Стандартна модель Асоціації учасників ринку облігацій - PSA.

Методика SMM показує, якою є частка дострокових повернень від залишку заборгованості в поточному місяці. Даний коефіцієнт розраховується у відсотках і має наступний вигляд:

$$
S M M=\frac{D_{E}-D_{F}}{D_{E}} * 100,
$$

де $D_{E}$ - розмір очікуваного залишку, $D_{F}-$ розмір фактичного залишку.

Умовний коефіцієнт дострокових повернень показує у процентному відношенні частку дострокових погашень в основній сумі боргу, і вираховується як приведена вартість SMM до річного базису:

$$
C P R=\left[1-\left(1-\frac{S M M}{100}\right)^{12}\right] * 100
$$


Модель PSA базується на тому, що коефіцієнт PSA має заданий часовий розподіл. Значення умовного коефіцієнту дострокових повернень лінійно зростає перші 30 місяців, а потім тримається на постійному рівні. Для стандартної кривої PSA початкове значення коефіцієнту складає 0,2 \% в перший місяць, а потім він зростає по 0,2 \% щомісячно, аж до 30-го місяця.

$$
P S A=\frac{C P R}{\min (\text { вiк_кредumy,30)*0,2 }} * 100
$$

Ризик інвестора ускладнюється набором різнорідних умов по кредитам - розмір процентних ставок, вік кредитів, тощо. Тому в міжнародній практиці прийнято визначати середні показники, що характеризують потік платежів в пулі активів [2].

Найпростішим показником статичних моделей оцінки ризику $є$ середня терміновість кредитів (WAM). Цей показник відображає середньозважений термін, що залишився до повного погашення кредиту.

$$
W A M=\frac{t_{1} D_{F_{1}}+t_{2} D_{F_{2}}+\ldots+t_{n} D_{F_{n}}}{D_{F_{1}}+D_{F_{2}}+\ldots+D_{F_{n}}},
$$

де $t_{i}-$ термін, що залишився до погашення, $D_{F}$ - розмір фактичного залишку, $n-$ кількість термінів дострокового погашення.

Для обрахунку міри ризикованості потоку платежів використовуються також показники дюрації Маколея та модифікованої дюрації, розроблені спеціально для ABS.

Дюрація Маколея виражає зважену в часі вартість потоків платежів, при чому виплати купонів інвестору $є$ незмінними при ймовірній зміні процентних ставок. Цей показник встановлює залежність між зміною ринкової ціни облігації та зміною доходності:

$$
\text { Дюраџฺiя }=\frac{1}{N}\left[\sum_{i=1}^{W A M} \frac{T_{i}^{*} C P M}{\left(1+r_{B} / 12\right)^{12 T_{i}}}\right],
$$

де $N$ - ринкова ціна облігації, $C P M-$ потік платежів позичальників, $T_{i}-$ час, що минув з моменту поставки до фактичного одержання виплат, $r_{B}-$ ставка доходності облігації.

Модифікована дюрація встановлює залежність зміни ціни від зміни доходності цінного паперу:

$$
\text { Модифікована_дюрачія }=\frac{\text { Дюраиія_Маколея }}{1+r_{B} / 12} .
$$

Таким чином, якщо скорочується термін до погашення кредиту, а також суми фактичних залишків, скорочується і показник WAM. Однак, якщо при обрахунку дюрації ставиться умова незмінності виплат інвесторам, то при ймовірній зміні потоків виплат за кредитами у часі, ризик нестиме банк. Встановити точний розмір ризику для банку не є можливим, оскільки він залежить від поведінкового аспекту позичальників, які за певних обставин можуть або затримувати платежі за тілом та відсотками, або достроково повертати суму кредитів.

Наступний ризик, яким стикається інвестор - ризик процентної ставки. Оцінка ризику інвестора при зміні процентної ставки обрахувати за допомогою дюрації Маколея чи модифікованої дюрації неможливо. Для цього існує динамічна модель обрахунку ризику-доходності інвестора в тому випадку, якщо існує коливання процентних ставок. Для початку розраховується показник ефективної дюрації, який враховує зміну доходності, надалі обраховується показник зміни ефективної дюрації при зміні ціни активу - опуклість (чи ефективна опуклість). На основі показників дюрації та опуклості розраховується відсотковий приріст ціни, і останній показник множиться на величину базової ціни. Таким чином, ми отримуємо ціну, кореговану на ризик зміни процентних ставок.

$$
\text { Ефективна_дюрачія }=\frac{P_{-\Delta}-P_{+\Delta}}{2 \Delta P_{0}},
$$

де $P_{-\Delta^{\prime}}, P_{+\Delta}-$ ціна з врахуванням зниження (підвищення) доходності на величину $\Delta, \mathrm{P}_{0}-$ базова ціна з незмінною доходністю, $\Delta-$ величина зміни доходності ${ }^{1}$.

$$
\text { Опуклість }=\frac{P_{-\Delta}-P_{+\Delta}-2 P_{0}}{100\left(\Delta^{2} P_{0}\right)}
$$

Тоді процентний приріст ціни складатиме 2 :

$$
\begin{aligned}
\Delta_{P}= & (\text { Едективна_дюрація } * \Delta)+ \\
& +\left[0,5 *\left(\text { Oпуклість } * \Delta^{2}\right)\right]^{*} 100
\end{aligned}
$$

Розрахункова ціна в умовах ризику складе:

$$
P_{\Delta r i s k}=P_{0} * \Delta_{P}
$$

Таким чином, ризик зміни процентних ставок збільшує додаткову премію доходності, що становить невід'ємну вимогу інвестора при розподілі волатильної доходності [3, сс. 138139; 150-152].

1 Зазвичай $\Delta$ в умовах задач вказується в базисних пунктах, а при розрахунку дюрації - в рамках відносного показника $\Delta / 100$.

2 Розрахунок приросту є приблизним, для більш точного обрахунку існує строго математична формула. 
Третім найвагомішим ризиком, з яким стикається інвестор, є ризик дефолту. На відміну від попередніх ризиків, він безпосередньо пов'язаний з діяльністю управляючими міжнародними проектами. [4]

Існує декілька методик оцінки ризику дефолту для ABS (MBS). Серед найбільш відомих та вживаних у світовій практиці можна виділити модель BMA та Z-модель Альтмана.

Модель BMA, розроблена Асоціацією учасників ринків облігацій (2001р.), представляє собою аналіз пов'язаних між собою розрахункових показників. Методика полягає в наступних кроках:

1. Визначається рівень залишку заборгованості (абсолютна величина) як різниця між залишком заборгованості за попередній період та: виплатою основного боргу за графіком, обсягами дострокових повернень, виплатами в результаті дефолту.

2. Обраховується загальна сума платежів шляхом множення іпотечної константи на величину початкового залишку заборгованості.

3. Розраховуються місячні процентні платежі.

4. Визначається сума погашення основного боргу (від загальної суми платежів віднімаються процентні платежі).

5. Встановлюється величина винагороди за обслуговування сек'юритизації (процент від початкового залишку).

6. Розраховується $\mathrm{CPR}$, і на його основі доля дострокових повернень:

$$
\text { Prepay_SMM }=100\left(1-\left(1-\frac{C P R}{100}\right)^{\frac{1}{12}}\right)
$$

7. Визначається рівень дострокових повернень як добуток показника Prepay SMM на різницю між початковим залишком та погашеною сумою за оригінальним графіком.

8. Розраховується показник умовної частоти дефолтів (CDR) як добуток швидкості дострокових повернень в результаті дефолту на різницю між початковим залишком та погашеною сумою за оригінальним графіком.

9. Визначається показник Default SMM, який описує модель: частка дострокових повернень в результаті дефолту не лінійно залежить від показника умовної частоти повернень [5, сс. 28-30].

Вагомий внесок у процесі моделювання ризику кредитів в умовах дефолту був представлений Е. Альтманом у 1963 та 1983 роках. Фактично, його Z-модель встановлює відношення між рівнем ризику за дефолтом та ключови- ми бухгалтерськими показниками діяльності фірми.

Модель Е. Альтмана побудована на основі апарату мультиплікативного дискримінантного аналізу, який будується на принципі максимальних дисперсій між групами, і мінімальних всередині груп. Для аналізу Е. Альтман дослідив дві групи компаній: перші - успішні, які згодом зазнали банкрутства, інші - успішні, які і залишилися успішними. Причини банкрутства дослідник знайшов у фінансових показниках, що відображені у звітах компаній. Розрахувавши коефіцієнти для 66 компаній, Е. Альтман отримав наступну модель:

$Z=1,2 K_{1}+1,4 K_{2}+3,3 K_{3}+0,6 K_{4}+0,999 K_{5}$,

де $Z$ - показник конкретної фірми-позичальника, яка потерпає від банкрутства. Він означає міру ризику, яка відображена у ймовірностях неповернення кредиту.

$K_{1}$ - відношення власного оборотного капіталу до суми усіх активів;

$K_{2}-$ відношення нерозподіленого капіталу до суми усіх активів;

$K_{3}-$ відношення величини прибутку до сплати відсотків і податків до суми усіх активів;

$K_{4}$ - відношення ринкової вартості власного капіталу до вартості позикового капіталу;

$K_{5}-$ відношення обсягів продажу до суми всіх активів.

Якщо $\mathrm{Z}<1,8$ - ймовірність банкрутства $\epsilon$ великою, таким позичальникам видавати кредит не рекомендовано. Якщо $1,81<\mathrm{Z}<2,99-$ необхідно проводити додаткові дослідження, оскільки цей проміжок $є$ зоною невизначеності. Якщо Z>2,99 - підприємство є доволі стійким, ризик дефолту позичальника $є$ невисоким.

В разі, якщо акції підприємства не проходять котирування на біржі, модель при попередніх показниках має наступний вигляд:

$$
\begin{aligned}
Z & =0,717 K_{1}+0,847 K_{2}+3,107 K_{3}+ \\
& +0,42 K_{4}+0,995 K_{5}
\end{aligned}
$$

Аналогічно граничні пороги для такої моделі становлять 1,23 та 2,9 [6].

Проте, модель Е. Альтмана при довгостроковому кредитуванні втрачає точність у зв'язку зі складністю розрахунку вказаних вище параметрів. Окрім цього, параметри моделі необхідно змінювати в залежності від країни, де існує підприємство, оскільки у різних економічних середовищах метод дає різні результати. Ще однією слабкою стороною моделі $є$ асиметрія інформації, яка може бути свідомо чи помилково викривленою у звітах компаній. Так, оцінка 
позичальників - італійських корпорацій - на предмет дефолту у процесі сек'юритизації дає суперечливі результати якраз через асиметрію інформації. [7]

Тому, існують інші моделі, що описують ризик дефолту для інвестора, наприклад, нечітко-множинний метод О.А. Недосєкіна, або метод нечітких нейронних мереж.

Модель О.А. Недосєкіна являє собою матричний метод прогнозування банкрутства і базується на обробці даних експертних оцінок змінних, які входять до системи моделювання даних. Рівням ризику присвоюють наступні значення: «Дуже низький, Низький, Середній, Високий, Дуже високий». [8]

Метод нечітко-нейронних мереж складається 3 дев'яти етапів.

На першому етапі визначають лінгвістичні змінні «Стану підприємства»: $E_{1}, E_{2}, E_{3}, E_{4}, E_{5}$; змінні «Ризику банкрутства»: $G_{1}, G_{2}, G_{3}, G_{4}, G_{5}$; змінні рівня показника $X_{i}: B_{i 1}, B_{i 2}, B_{i 3}, B_{i 4}, B_{i 5}$.

Другий етап починається з побудови набору окремих показників $X=\{X i\}$ із загальним числом $N$, які, на думку експерта, можуть впливати на оцінку ризику банкрутства та відображають стан діяльності та фінансову сторону підприємства.

На третьому етапі кожному показникові $X_{i}$ присвоюють значимість.

Четвертий етап передбачає побудову класифікації ступенів ризику на певному заданому інтервалі $g$ із розбиттям множин аналізованих параметрів на підмножини. При цьому визначається ступіть оціночної впевненості чи функції належності.

На п’ятому етапі конструюють поточні значення $x$ показників $X$ у якості критерію поділу множини їх значень на підмножини $B$.

Оцінку рівня показників на шостому етапі подають у зведеному табличному форматі (табл. 1).

Табличя 1

ПОТОЧНИЙ РІВЕНЬ ПОКАЗНИКІВ, ЩО ВПЛИВАЮТЬ НА ОЦІНКУ РІВНЯ БАНКРУТСТВА ПІДПРИЄМСТВА

\begin{tabular}{|c|c|}
\hline Показник & Поточне значення \\
\hline$X_{1}$ & $x_{1}$ \\
\hline$\cdots$ & $\cdots$ \\
\hline$X_{i}$ & $x_{i}$ \\
\hline$\cdots$ & $\cdots$ \\
\hline $\mathrm{X}_{\mathrm{N}}$ & $\mathrm{x}_{\mathrm{N}}$ \\
\hline
\end{tabular}

На сьомому етапі проводиться класифікація поточних значень $x$ за критерієм із табл. 1 , а також визначається належність носія $x_{i}$ до нечітких підмножин $B_{j}$.

Восьмий етап присвячений оцінці міри ризику банкрутства. На усьому етапі відбувається присвоєння ваг підмножинам із категорії $B$ для оцінки стану корпорації $E$ та оцінки ступеню ризику $G$.

Завершальний дев'ятий етап передбачає класифікацію значень ступеню ризику на основі отриманих у процесі аналізу даних. В результаті дослідження робиться висновок про ступінь ризику банкрутства та ступінь впевненості експерта у правильності його класифікації. [9]

3 одного боку, метод Недосєкіна дозволяє поєднати кількісний та якісний аналізи у одну модель, яка є чіткою та зрозумілою за алгоритмом послідовних дій з оцінки ризику банкрутства. При цьому врахування у моделі неточних значень нейронних мереж надає цьому методу гнучкості у роботі з асиметричною інформацією. 3 іншого - експертні оцінки можуть не давати бажаної точності у розрахунках, адже цей метод відкриває можливості для експериментальних досліджень, таких, як, наприклад, алгоритм Мамдані. [10]

Як бачимо, навіть для трьох обраних нами для аналізу кредитних ризиків банку для інвестора - дострокових повернень, зміни процентної ставки та дефолту позичальників - існують різні підходи до оцінки, а тому перспективи побудови єдиної загальної моделі оцінки комплексу загроз інвестування у фінансові інструменти сек'юритизації залишаються актуальними дотепер.

\section{ВИСНОВКИ ТА ПЕРСПЕКТИВИ ПОДАЛЬШИХ ДОСЛІДЖЕНЬ}

Отже, структуровані інструменти сек'юритизації дозволяють, з одного боку передати кредитні, а інколи і виробничі ризики міжнародних інвестиційних проектів інвесторам, з іншого - залучити інвестиції в проект на базі майбутніх надходжень від кредиторів. Для інвестора інструменти сек'юритизації слугують інструментом диверсифікації ризиків, методики оцінки яких і було представлено вище. У той же час інвестор виступає носієм ризиків, пов'язаних із кредитуванням позичальників, найважливішими 3 яких є ризики дострокових повернень кредитів, ризики зміни процентних ставок та ризики дефолту позичальників. Для того, аби управляти цими видами ризиків, необхідно провести належну їх оцінку, сформулювати підходи до ідентифікації небезпек, пов'язаних із потоком грошових коштів. 
У сучасній науці відсутній єдиний підхід до комплексного управління ризиками кредитного характеру. Це зумовлено, найперше, виключною складністю моделювання грошово-кредитних процесів, пов'язаних факторами часу виконання угод та подіями, які вносять корективи до графіку погашень кредитів.

Наукові дослідження доводять, що остання фінансово-економічна криза була недостат- ньо прогнозована через відсутність належної оцінки ризиків структурованих фінансових інструментів. Нині перспективи подальших досліджень кредитних ризиків полягають у формуванні уніфікованої моделі карти ризиків на основі не лише статичного, а й динамічного аналізу із активним залученням методів експертних оцінок.

\title{
СПИСОК ВИКОРИСТАНИХ ДЖЕРЕЛ
}

1. Slime B. Credit Name Concentration Risk: Granularity Adjustment Approximation. Journal Of Financial Risk Management, 2016, 5, 246-263 http://Dx.Doi.Org/10.4236/Jfrm.2016.54023

2. Angelfire. Fixed income analysis. [Електронний ресурс]. - Режим доступу: http://www.angelfire.com/ ma3/gillsie/CFA2/Fixed\%20Income\%20Analysis.pdf

3. Дэвидсон Э., Секьюритизация ипотеки: мировой опыт, структурирование и анализ. / Э. Дэвидсон, Э. Сандерс, Л.-Л. Вольф, Ф. Чинг - М.: «Вершина», 2007. - 592 с.

4. Yueliang Su, Baoyu Zhong. The Credit Risk Assessment Model Of Internet Supply Chain Finance: MultiCriteria Decision-Making Model With The Principle Of Variable Weight. Journal Of Computer And Communications, 2016, 4, 1-11 http://dx.doi.org/10.4236/jcc.2016.416001

5. Sunil Gangwani, Deloitte \& Touche LLP. MBS Structuring: Concepts and Techniques. // The Securitization Conduit. - 2008. - Vol. 1, №. 3. - P. 26-37.

6. Анализ финансового состояния предприятия. Модель Альтмана (Z-Модель). Пример расчета. [Електронний ресурс]. - Режим доступу: http://afdanalyse.ru/publ/bankrostvo/bankrot_1/13-1-0-10

7. Bedin, A., Billio, M., Costola, M., Pelizzon L. Credit scoring in sme asset-backed securities: an italian case study. J. Risk financial manag. 2019, 12(2), 89; https://doi.org/10.3390/jrfm12020089

8. Недосекин А.О. Комплексная оценка риска банкротства корпорации на основе нечетких описаний. Международная научная лаборатория по внедрению нечеткомножественных подходов в экономических исследованиях. [Електронний ресурс]. - Режим доступу: http://www.ifel.ru/br7/3.pdf

9. Ісаєва Т.М. Нечітко-множинний підхід до оцінки ризику банкрутства підприємства. Вісник Бердянського університету менеджменту і бізнесу № 1 (17) 2012. сc. 108-113. [Електронний ресурс]. - Режим доступу: http://old.bumib.edu.ua/sites/default/files/visnyk/19-1-17-2012.pdf

10. Зайченко Ю., Рогоза С., Столбунов В. Сравнительный анализ методов оценки риска банкротства предприятий Украины. International Book Series «Information Science and Computing». [Електронний pecypc]. - Режим доступу: http://foibg.com/ibs_isc/ibs-07/IBS-07-p15.pdf

\author{
Подвысоцкий Ян Владимирович \\ Кандидат экономических наук, ассистент \\ Киевский национальный университет имени Тараса Шевченка, \\ Институт международных отношений, \\ 2. Киев, Украина \\ ORCID ID 0000-0001-7944-6248 \\ e-mail:yanpidvysotskiy@gmail.com
}

\section{ПРОБЛЕМЫ ОЦЕНКИ КРЕДИТНЫХ РИСКОВ СТРУКТУРИРОВАННЫХ ФИНАНСОВЫХ ИНСТРУМЕНТОВ}

\begin{abstract}
Аннотация. Подходы к оценке рисков структурированных финансовых инструментов, а именно ценных бумаг, обеспеченных активами, в современной финансовой инженерии недостаточно систематизированы. Причинами этого могут стать разнообразие рисков, которые банк желает избежать, передав в управление другим сторонам; недостаточное внимание к селекции заемщиков; отсутствие консолидации по вопросам формирования единой методики оценки типичных рисков.
\end{abstract}


Автор представляет для анализа три основных вида рисков, с которыми сталкивается банк в процессе осуществления секьюритизации: риск досрочного возврата кредита, риск изменения прочентной ставки и риск дефолта контрагента. В основе оценок лежат факторы времени и события, которые при определенных условиях могут критически влиять на денежные потоки финансовых учреждений.

Риски досрочного возврата связанные с расчетом усредненных значений времени до наступления выплат по кредитам, однако унифицированная методика оценки в банковской практике пока отсутствует. Оченка степени риска сопровождается расчетом прочентного прироста к базисной цене с неизменной доходностью. Прирост отражает риск изменения процентной ставки в течение определенного времени.

Особое внимание в статье автор уделил анализу методов оценки дефолта контрагента структурированного инструмента. Установлено, что методика Э. Альтмана при разных условиях экономической среды может давать противоречивые результаты. Поэтому в последние годы оптимальными моделями оченки риска дефолта можно считать модели нечетко-нейронных сетей. Взятая за основу методика А.А. Недосекина показывает степень риска банкротства заемщика, опираясь на методы экспертных оченок. С одной стороны, модель нечетко-нейронных сетей может давать приближенные к истине результаты, с другой - на точность результата может влиять асимметрия информации, на основе которой строит оценку определенный эксперт. В таком ключе эта модель требует дальнейших усовершенствований, которые предлагают современные японские ученые на основе критерия Мамдани.

Таким образом, проблематика оченки кредитных рисков структурированных инструментов остается актуальной в современных научных кругах и требует выработки общих идей унификации методик, предлагаемых современной наукой.

Ключевые слова: кредитный риск; структурированный финансовый инструмент; досрочный возврат; процентная ставка; дефолт.

\author{
Yan Pidvysotskyi \\ PhD in Economics, assistant professor \\ Taras Shevchenko National University of Kyiv, \\ Institute of International Relations, \\ Kyiv, Ukraine \\ ORCID ID 0000-0001-7944-6248 \\ e-mail:yanpidvysotskiy@gmail.com
}

\title{
PROBLEMS OF EVALUATING CREDIT RISKS OF STRUCTURED FINANCIAL INSTRUMENTS
}

Annotation. Approaches to the risk assessment of structured finance instruments, in particular assets backed securities, are not sufficiently systematized in modern financial engineering. The reasons for this may be: the variety of risks that the bank tries to avoid by passing on to other parties; inappropriate attention to selection of borrowers; lack of consolidation on common methodologies for estimating typical risks. The author presents for analysis three main types of risks a bank encounters during the securitization process: early repayment risk, interest rate risk and counterparty default risk. The estimates are based on time factors and events that under certain conditions can have a critical impact on the cash flows of financial institutions.

Early loan repayment risks relate to the calculation of average time values, but there is currently no unified methodology for assessing in banking practices. Risk assessment is accompanied by the calculation of the percentage increase to the base price with unchanged yield. The growth reflects the risk of changing the interest rate over a period of time.

The author focuses on the analysis of methods for default assessing of a structured instrument. It is established that the method of E. Altman in different conditions of the economic environment can give contradictory results. Therefore, in recent years models of fuzzy-neural networks can be considered as the best models for estimating default risk. Taken as the basis of the method O.A. Nedosekin shows the risk degree of bankruptcy of the borrower, based on the methods of expert assessments. On the one hand, the model of fuzzy-neural networks can give results that are close to be true, on the other hand, the accuracy of the result may be affected by the asymmetry of information which certain expert uses to assign values. In this 
way, this model needs further improvements that are offered by modern Japanese scientists based on the Mamdani criterion.

Thus, the problem of assessing the credit risks of structured instruments remains relevant in today's academic circles and requires the development of common ideas for the unification of techniques offered by modern science.

Keywords: credit risk; structured financial instrument; early return; interest rate; default.

\section{REFERENCES (TRANSLATED AND TRANSLITERATED)}

1. Slime B. Credit Name Concentration Risk: Granularity Adjustment Approximation. Journal Of Financial Risk Management, 2016, 5, 246-263 http://Dx.Doi.Org/10.4236/Jfrm.2016.54023 (in English)

2. Angelfire. Fixed income analysis. Retrieved from: http://www.angelfire.com/ma3/gillsie/CFA2/Fixed\%20 Income\%20Analysis.pdf (in English)

3. Davison, A., Securitization: Structuring and Investment Analysis. / Davison, A., Sanders, A., Wolf, L-L, Ching, A. - M.: «Vershina», 2007. - 592 p. (in Russian)

4. Yueliang Su, Baoyu Zhong. The Credit Risk Assessment Model Of Internet Supply Chain Finance: MultiCriteria Decision-Making Model With The Principle Of Variable Weight. Journal Of Computer And Communications, 2016, 4, 1-11 http://dx.doi.org/10.4236/jcc.2016.416001(in English)

5. Sunil Gangwani, Deloitte \& Touche LLP. MBS Structuring: Concepts and Techniques. // The Securitization Conduit. - 2008. - Vol.1, №. 3. - P. 26-37. (in English)

6. Analysis of financial condition of enterprise. Altman's model. Example of calculation. Анализ Retrieved from: http://afdanalyse.ru/publ/bankrostvo/bankrot_1/13-1-0-10(in English)

7. Bedin, A., Billio, M., Costola, M., Pelizzon L. Credit scoring in sme asset-backed securities: an italian case study. J. Risk financial manag. 2019, 12(2), 89; https://doi.org/10.3390/jrfm12020089(in English)

8. Nedosekin, A.O. Complex assessment of bankruptcy of corporation based on fuzzy descriptions. International Fuzzy Economics Lab. Retrieved from: http://www.ifel.ru/br7/3.pdf (in Russian)

9. Isaeva, T.M. Fuzzy-multiple approach to assessing the risk of bankruptcy of an enterprise. Journal of Berdyansk University of Management and Business № 1 (17) 2012. pp. 108-113. Retrieved from: http:// old.bumib.edu.ua/sites/default/files/visnyk/19-1-17-2012.pdf (in Ukrainian)

10. Zaychenko, Yu., Rogoza, S., Stolbunov, V. Comparative analysis of methods for assessing the bankruptcy risk of Ukrainian enterprises. International Book Series «Information Science and Computing». Retrieved from: http://foibg.com/ibs_isc/ibs-07/IBS-07-p15.pdf (in Russian) 